\title{
From Culture to People: Thinking Anthropologically with Jesus and Paul
}

\author{
Johannes Merz
}

\begin{abstract}
The culture concept has been crucial to anthropology. Yet, I argue against its use. I examine how Jesus and Paul interacted with, and focused on, people and contend that we shift our attention from culture to people. Human diversity and difference should no longer be categorized into different cultures as relative, bounded and divisive units. Rather, we should view it as an integral part of humanity's commonality. Shifting our attention to people as cultural beings also means a move beyond a preoccupation with knowledge by embracing practical, reflexive, and ontological engagements with others. It is only when we try to understand specific people's diverse perspectives and the way they see themselves and the world, that we can take them seriously. This opens up anthropology, both at a theoretical level and by collaborating with other disciplines, including theology.
\end{abstract}

\section{Introduction}

Jesus and Paul were not anthropologists. They could not have been, since anthropology-at least as an academic discipline-was only invented during the late nineteenth century. Yet, Jesus and Paul demonstrated an astute awareness of their complex multicultural and multilingual societies. Their words and actions, as recorded in the New Testament, show that they reflected on social, cultural and religious issues, challenged conventions and authority, and deconstructed identities, both their own and those of others. This permitted them to focus on people regardless of their diverse backgrounds. In this, Jesus' and Paul's thoughts and practices model for us how to think anthropologically remarkably well.

I find no evidence in the New Testament that Jesus and Paul used the word "culture," nor the anthropological concept associated with it. This contrasts with Alan Barnard and Jonathan Spencer's observation that "[t]he word 'culture' is probably the single most central concept in twentieth-century anthropology" (2010, 168). Today, however, anthropology is shifting towards studying humanity and humans in all their diversity by focusing on people rather than culture.

In this article, I discuss the rise, fall, and persistence of the culture concept in academic anthropology, as well as its popularization in other academic disciplines and among the wider public. Originating from the convergence of Romanticism and the Enlightenment, the idea of culture became one of the first concepts of academic anthropology and thus shaped the new discipline's conceptual and methodological approach. More recently, however, the culture concept has been widely discussed and contested. I argue in line with many other current anthropologists that we should limit ourselves in using the idea of "culture" to a broad and descriptive sense by only using it as an adjective or adverb. This means that we need to shift our attention away from culture as a concept towards the question of what it is to be human. Cultural diversity and difference remain part of anthropology's focus, but rather than considering them as relative in cultural terms, I propose to root them in human commonality by following the example set by Jesus and Paul. In other words, we are different from each other because we are humans.

Rodseth noted that anthropology's culture concept has "proven to be exceedingly complex" (2018, 399). We simply cannot do without generalizations when talking about culture and anthropology more generally. While I criticize the culture concept for its generalizing stance, I do so for its potentially divisive and relativizing impact. The problem with generalizations is that they are never neutral, since we use them to highlight some aspects at the expense of others. In this sense, most of this article is concerned with how I think we should generalize about culture, diversity, difference, and humans, while seeking to avoid the pitfalls and concerns of earlier approaches. 
I start by discussing how anthropologists established their new discipline in opposition to other disciplines, notably theology. This provided the basis on which the culture concept could develop. I then sketch the history of the culture concept from its origins to it becoming the central concept of American anthropology in the early twentieth century. It was this period that was most important in shaping the culture concept, leading to its popularization in other academic disciplines as well as among the wider public.

With the crisis of representation in anthropology of the 1980 s, scholars started to question and debunk the culture concept. Although "culture" had been useful to think and talk about human difference in general terms, many anthropologists now considered it deeply flawed. People too easily reify and essentialize "culture" so that it dominates humans, which results in generalizations and stereotypes. The culture concept, then, created the divisions between people that anthropologists sought to understand and overcome. In spite of such critique, "culture" continues to be a popular concept among some anthropologists, in other academic disciplines, such as theology, and especially among the wider public. I then turn to Jesus and Paul to examine how they dealt with diversity and difference by focusing on people.

In the last section, I pull the different strands of the argument together, contending that current ontological anthropology provides a framework for anthropologists to focus on people and to take them seriously by relationally and reflexively engaging with them. By deconstructing and debunking the culture concept and its divisive boundaries, we can rid ourselves of dichotomies and divisions that have plagued anthropology as a discipline. I am not suggesting that we should abandon the important and valid idea of culture when used as an adjective to describe human difference and diversity. By doing so, we shift our focus to taking people seriously as cultural beings, as we find them, and how they see themselves. This includes their conceptual ideas, which should not only supply anthropology with data but also inform theory and contribute further to the discipline at all levels. Such developments should also promote collaboration with other disciplines, such as theology.

\section{Establishing Anthropology against Theology}

Fascination with human otherness may be as old as humanity itself, but it was only during the late nineteenth century that European scholars moved from describing otherness to analyzing and explaining it systematically and theoretically, notably through the culture concept. This marked the beginning of academic anthropology, which-like other scientific disciplines-has its roots in Christian theology.
Following the collapse of the Roman Empire, Christian priests and monks maintained Antiquity's intellectual and philosophical heritage by pursuing their theological interests. During the Middle Ages monasteries and cathedral schools developed from centers of leaning into universities, paving the way for Europe's academic and scientific development.

The age of exploration piqued a renewed interest in human diversity with explorers, traders, missionaries, and later colonialists starting to document their observations of human otherness. More systematic and philosophical reflection on humanity, especially in terms of its origin and nature, however, remained part of theology. Anthropology as an academic discipline distinct from other academic disciplines only developed much later, as a result of the "the ongoing secularisation of European intellectual life, the liberation of science from the authority of the Church, and the relativisation of concepts of morality and personhood" (Eriksen and Nielsen 2013, 7). These developments culminated during the nineteenth century in European academics establishing "scientific unity via an opposition between 'science,' now fully identified with reason, and 'religion,' increasingly associated with faith or perspectival belief” (Josephson-Storm 2017, 60).

The time was now ripe for Edward Burnett Tylor (1832-1917) to be appointed first as reader in anthropology at Oxford University in 1884, then as professor of anthropology in 1896 (Eriksen and Nielsen 2013, 30-31; Larsen 2014, 13-36; J. D. Moore 2009, $5-17)$. While anthropology had been in the making for a while, its first professorship marked a crucial step in establishing it as a scientific discipline.

Through the emerging scientific paradigm based on the idea of evolution, early anthropologists positioned themselves in opposition to the rest of the world (AbuLughod 1991, 139) and adopted a strong anti-religiousand often anti-Christian-position (Larsen 2014, 9, 30). Accordingly, many early anthropologists, including Tylor, rejected the faith of their parents and "assumed that theology and anthropology were incompatible, competing modes of thought rather than potentially complementary or mutually enriching ones" (Larsen and King 2018, 51). This attitude has underpinned anthropology ever since and came to define disciplinary boundaries based on the question of God's existence: "Christian theology could not function without belief in God, while anthropology operates perfectly naturally without it" (Davies 2002, 1). Anthropologists have tried to approach the subjects of their study without preconceived ideas by ridding themselves of what they perceived to be any form of subjectivity, particularly religion, that appeared to hinder scientific neutrality and objectivity as they studied those who were different. Anthropologists used this self-relativizing stance also to 
set themselves apart from other academics and their disciplines, notably theology.

Anthropology's separatist, self-relativizing and antireligious stance shaped the discipline's development in significant ways, sometimes to its own detriment. Larsen and King (2018) recently documented how early antireligious anthropologists rejected biblical accounts and thus declared Genesis a myth. This led them to embrace a polygenetic origin of humanity, which they justified through the human diversity they observed. Their position, however, was never accepted in anthropology and has since been fully refuted by geneticists, who affirm the biological unity of humanity (Engelke 2018, 168-169).

This example shows how early anthropologists were not only contrary; they actively tried to establish and legitimize their new discipline as a distinctive and valid science, often by explicitly demarcating it from their perceived subjectivity of religion and theology. Anthropology did indeed become a small but respected and respectable discipline, in spite of its short history plagued with problems and controversies (see, for example, Eriksen and Nielsen 2013; J. D. Moore 2009).

The idea of culture as an analytic concept was maybe the most important anthropological innovation. Culture came to be for anthropology what God is for theology: "the concept can be better understood as part of a belief system" (J. H. Moore 1974, 537). In due course, the culture concept proved so successful that it moved beyond the discipline's boundaries and has become an important part of everyday vocabulary. Today, it is so ubiquitous that hardly a day goes by when I do not hear the word "culture" at least once outside strict anthropological circles, be it in the news and other media, socializing with friends, or in my work for SIL International, a faith-based NGO.

While I welcome a heightened awareness of cultural issues in wider society, the culture concept-both in its anthropological and popularized form-comes with serious issues that I see rooted in anthropology's origins. Culture's usefulness and limitations continue to be debated in current anthropology, with more skeptical voices debunking the concept behind it. Robert Brightman observed "that the culture concept has been flawed from its inception” (1995, 509; see also, Engelke 2018; Rodseth 2018), an observation that deserves a more thorough examination and evaluation in the light of anthropology's history.

\section{Anthropology and the Culture Concept}

The idea of culture in anthropology can be traced back to Jean-Jacques Rousseau (1712-1778) and Johann Gottfried Herder (1744-1803), and the convergence of Romanticism with the Enlightenment.
Anthropology inherited an interest in cultural wholes from Romanticism, while the Enlightenment contributed its analytical, comparative and classifying approach (Eriksen and Nielsen 2013, 15).

Tylor starts his book Primitive Culture (1871) with anthropology's first and most influential definition of culture mainly by drawing on Romantic ideas: "Culture or Civilization, taken in its wide ethnographic sense, is that complex whole which includes knowledge, belief, art, morals, law, custom, and any other capabilities and habits acquired by man as a member of society" (1871, 1). Tylor never pluralized culture (Barnard and Spencer 2010, 170), thus presenting it as an inclusive but vague abstract whole that has often been criticized for defining everything yet nothing specific.

Franz Boas (1858-1942), of Jewish German origin, introduced anthropology to America. He was familiar with Herder's ideas about culture, picked up Tylor's definition of culture and drew on early anthropologists' self-relativizing and anti-religious stance. Yet, he was never interested in theorizing culture and hesitantly presented a coherent view of it with an essentially Tylorian definition towards the end of his career (Kroeber and Kluckhohn 1952, 45, 151). His main contribution to the culture debate was to counter the view of his time that culture was an expression of race and would evolve. He did so by coining the idea of cultural relativism, by which he meant that "without relativising your own culture, you can have no hope to understand another" (Eriksen and Nielsen 2013, 60).

Several of Boas' students such as Ruth Benedict, Margaret Mead, and Alfred Kroeber, continued to develop and formalize the idea of culture, turning it into "the central concept of anthropology" (Kroeber and Kluckhohn 1952, 36). Like Boas, they advocated Tylor's Romantic ideas about culture, but also developed the concept's Enlightenment legacy. While they viewed culture as an expression of behavior, their main innovation was to propose that cultural differences between societies could be expressed in terms of different cultures. Having pluralized culture, it now served anthropologists as a classificatory, analytic and comparative idea to conceptualize difference. Culture thus became anthropology's main object of study, especially in America.

Boas and his students were aware that the culture concept could lead to generalizations. While they stressed the importance of treating cultures as wholes, they also viewed each culture as distinct. This is why they thought it was important to study each specific situation in detail with the aim of finding the patterns and configurations that characterized different cultures. Each culture deserved to be described minutely and methodically, which was particularly important in view of many small-scale societies whose cultures appeared to be threatened by colonization, imperialism, and 
globalization. Studying the culture of a specific people thus became a kind of "salvage ethnography" (J. D. Moore 2009, 62, 67) with the aim of preserving what soon would be lost.

The last important anthropologist whose ideas about culture were influenced by the Boasians was Clifford Geertz (1926-2006; Rodseth 2018, 406-407). He further developed the culture concept by viewing the idea of culture in terms of meaning, rather than behavior. He proposed a refined and more focused, yet abstract and semiotic, meaning-based definition, which treats culture as if it were a literary text. For him, culture is "an historically transmitted pattern of meanings embodied in symbols, a system of inherited conceptions expressed in symbolic forms by means of which men communicate, perpetuate, and develop their knowledge about and attitudes toward life" (1973, 89). Culture as a system of meaning and symbols thus helps people to make sense of the world they inhabit, as they live out their lives within it.

Geertz's take on culture reinforced the concept's Enlightenment legacy and further stressed difference and alterity between cultures to the extent that different cultures become defined by their distinctiveness. Thus, it is only within the limits of a specific culture that people's behavior, beliefs, and practices become meaningful, rendering it "unknowable to the etic [outside] observer, since the meanings are only obtainable from the emic insider's point of view" (J. D. Moore 2009, 228). In this sense, Geertz foreshadowed the "crisis of representation" (Marcus and Fischer 1986) that led to efforts to debunk the culture concept.

Many anthropologists outside of America were also skeptical about the culture concept. In British anthropology, for example, A. R. Radcliffe-Brown (1881-1955) famously dismissed culture as "a vague abstraction" (1952, 190) and preferred to focus on studying society instead. This led to British social anthropology being distinguished from American cultural anthropology, even though both traditions remained part of the same discipline. Indeed, the difference between culture and society has not always been obvious and the two notions tended to be used synonymously (Kroeber and Kluckhohn 1952, 36).

A. L. Kroeber and Clyde Kluckhohn $(1952,36)$ acknowledged that the culture concept took time to be established as a general idea. Culture, in its anthropological sense first introduced by Tylor (1871), only appeared in Webster's dictionary in 1929 and in the 1933 supplement of the Oxford dictionary. By 1940 the educated anglophone public started to use it (Kroeber and Kluckhohn 1952, 33, 35). Especially Benedict's and Mead's work contributed to the popularization of the culture concept. Some of their books (for example, Benedict 1934; Mead 1928) had become classics and still count among the most widely read anthropological works today.

Scholars of other disciplines also took up the culture concept and applied it to their disciplines, including theology (Carson 2008; Gorringe 2004; Nehrbass 2016; Niebuhr 1951) and missiology (Meneses 2009; Merz 2020). Such efforts resulted in a significant and lasting contribution that established the concept well beyond anthropology.

Scholars of various disciplines, and the wider public alike, currently seem to use the culture concept even more copiously than ever before. They often take culture as a given and talk about it rather vaguely in order to generalize differences between people and societies. In doing so, they reinforce both the Romantic idea of cultural wholes and the Enlightenment traits of classification and demarcation. Both scholars and the general public, then, have accepted the culture concept much more readily than many anthropologists, who continue to discuss and often contest it.

Despite its popularization-or maybe because of itanthropologists took the culture concept increasingly to task and by the 1990s "successfully discredited the old notion of 'a people' sharing 'a culture" (Eriksen and Nielsen 2013, 202) and a language (Schwartz 2018), while occupying a specific delimited space (Gupta and Ferguson 1992).

In hindsight, the culture concept has never been as romantic or enlightening as it initially appeared. Having been embraced by the wider public, however, it continues to prove hard for anthropologists to counter the ever-popular concept. This being the case, I think it is important to revisit how anthropologists critique and deconstruct the culture concept in more detail.

\section{Debunking the Culture Concept}

As part of the crisis of representation in anthropology during the 1980s, the landmark book Writing Culture (Clifford and Marcus 1986) "was received as a single-minded assault on the dominant concept of culture" (Eriksen and Nielsen 2013, 180). Coming from the perspective of literature criticism, scholars looked at how anthropologists represented the people and societies they studied and thus also paid attention to the culture concept. James Clifford observed: "'Cultures' do not hold still for their portraits" $(1986,10)$, thus questioning the value of documenting a culture in the face of the perpetual changes that contemporary societies face. He continued: "If 'culture' is not an object to be described, neither is it a unified corpus of symbols and meanings that can be definitively interpreted. Culture is contested, temporal, and emergent” (Clifford 1986, 19).

Clifford set both the tone and the agenda for the culture concept's deconstruction and later debunking, 
questioning both the concept's Romantic and Enlightenment roots and thus identifying it as an ideological construct. The attack was broad, ranging from simple questions of how the culture concept deals with change, or the fuzzy distinctions between societies, to deeper and more fundamental questions of how the culture concept affects the way we think about those who are different. It is these latter foundational ideas that I continue to explore.

Roger M. Keesing pointed out that the culture concept "almost irresistibly leads us into reification and essentialism” (1990, 48). In other words, it invites us to treat culture as if it were an object or thing that we can study, learn, know, and compare. This divides humanity into different cultures, which are seen as being bounded, distinct, uniform, and thus demarcated from each other.

Having been reified, culture can apparently be animated and transformed into "a living being or something developing like a living being” (Brumann 1999, 2). Keesing observed that he hears "colleagues and students talk as if 'a culture' was an agent that could do things" (1990, 48, emphasis in original). While I worked on this article, I came across many examplesboth in academic and popular discourse-that treated culture as an actor that perceives, assumes, values, encourages, rejects, invests, creates, tells, dictates, spends time, and even worships, believes, and thinks, and so on. In doing so, culture displaces humans from anthropology's center of attention, takes on their agency, and then dominates and determines their lives.

Reifying and claiming to know a culture easily leads to essentialism, which is the assumption that a culture allows us to know the people who are thought to be part of it. Especially in the popularized use of the culture concept, this easily results in stereotypes, which come to define whole "cultures." Some common popular stereotypes are, for example, that Americans are ignorant, that Mexicans are lazy, that Muslims are terrorists, that Africans are animists, that Amazonian Indians are oral, and that the Middle East has a shame culture (Merz 2020). People who do not conform to stereotypes can then easily be ignored and even stigmatized. Today, anthropologists readily recognize that even small-scale societies are simply too complex to make valid generalized statements like these. Despite this, reducing social complexities to the idea of a single culture remains attractive, especially in popular discourse, since this provides easy labels and the means to talk about difference. To do so, however, fosters a silo mentality that goes back to the advent of academic anthropology.

People commonly use essentialized stereotypes to compare, value, and judge others, usually by setting them apart, more often negatively and depreciatively than not. In this sense the culture concept is also ideological, political and hegemonic (J. H. Moore 1974; Rodseth 2018; Schwartz 2018). While I do not see the culture concept as the cause of stereotyping and generalizing others-people have always done this-I do think that people use it to legitimize these activities. Similarly, the essentializing tendencies of the culture concept resulted in its penetration to the core of anthropological theorizing, often with anthropologists not sufficiently recognizing it. The way people have used the culture concept thus systematically contributed ideas and rationales that facilitated some of the most tragic events in human history, such as colonialism, the Holocaust, the Rwandan genocide, as well as widespread contemporary racism and xenophobia. Historically linked to nationalism and language (Eriksen and Nielsen 2013, 16-17; Schwartz 2018), people have used an essentialized culture concept not only to discredit those who are different, but also to create unity and patriotism in order to bolster their own position.

The way the culture concept works is that those who draw on it use their language and associated concepts as an authoritative basis from which to approach and study those who are different (Brumann 1999, 2). Having identified and abstracted a group of people as a culture, it can then be studied from a detached distance by analyzing it in terms of difference. This is done through an act of interpretation from within the established academic discourse determined by the culture concept (Kahn 1989, 11), rather than through observation (Silverstein 2005, 103, 111). In other words, we use the culture concept to seek to understand difference by making it conform to our way of thinking. This then clouds how we comprehend others and the way they see and understand themselves.

As a result of using the culture concept, we then gain the impression that we understand human difference better, thereby reinforcing how we think and see ourselves in opposition to those who are different. While this seems to make otherness easily accessible, and can produce insights about other people's ways of life, anthropology's culture concept actually becomes "the essential tool for making other" (Abu-Lughod 1991, 143). The culture concept is thus essentially divisive, even if we employ it positively by seeking to promote understanding across cultures.

The culture concept, then, digs the trenches it seeks to bridge. Together with cultural relativism it has regularly pushed anthropologists to stress difference and alterity sometimes to the extent of concluding that different cultures are incommensurable. In other words, different cultures came to be seen as so distinct that it was inconceivable to see and accept any commonality between them. This kind of hyperrelativism then inevitably questions the unity of humanity and the possibility of effectively engaging with 
people when doing anthropological research. With this, the culture concept-at least as it was developed by the Boasians-caves in on itself.

\section{Culture Today}

Even though many anthropologists raised issues about the culture concept and debunked it, others like Christoph Brumann (1999) or Carola Lenz (2017) argue for its continued use in anthropology more or less unchanged. In practice, most anthropologists recognize both weaknesses and strengths of the culture concept and many seek to navigate a middle ground. So crucial has the idea of culture been to anthropology and the wider world that most anthropologists are not willing to let go of it completely. Rodseth observes: "'Culture' is still with us, . . . but in a greatly modified and perhaps diminished form" (2018, 399).

In order to maintain the benefits behind the idea of culture, but reject the generalizing, reifying, and essentializing stance of it as an ideological concept, Keesing (1990, 57) suggested that we avoid the noun culture, while Brightman $(1995,501)$ proposed to continue using it as an adjective (or adverb). This pragmatic self-limiting use of "culture" has since gained traction (Barnard and Spencer 2010, 175; Brumann 1999, 3-4; Engelke 2018, 51; Merz 2020, 136; Silverstein 2005).

Avoiding culture as a noun means that we withdraw from Enlightenment ideas that influenced the Boasians' culture concept, while retaining some of the Romantic notions. Thus, we no longer need to constrain the complex, dynamic, and fuzzy idea of cultural wholes by providing definitions, which are always deficient and contestable. Matthew Engelke (2018, 25), for example, is not willing to define culture as a concept, but he recognizes that we need to describe what we mean in order to retain the notion's usefulness. Good and succinct descriptions have already been provided in the past, for example by James P. Spradley: “Culture . . . refers to the acquired knowledge that people use to interpret experience and generate social behavior" $(1979,5)$. I find Engelke's description, which echoes Geertz's definition, also helpful: "Culture is a way of seeing things, a way of thinking. Culture is a way of making sense" (2018, 27).

In practice, when we consider using the word "culture," we first need to ask if there is not a better, more precise word that could take its place. Anthropology has always had a much wider, more nuanced and flexible conceptual repertoire to fall back to in order to explain difference and diversity. Such alternatives to culture include society, community, identity, worldview, life, custom, heritage, thought, discourse, ideology, and people. Words and ideas like these not only avoid the danger of reifying, essentializing, or animating the idea of "culture," they actually help us to communicate ideas more clearly. When we think that the word culture would be justified, we should consider an adjectival expression instead, such as cultural environment, cultural background, cultural issue, cultural change, or cultural feature. Such adjectival expressions that attribute "culture" to other nouns help us to be more precise in our vocabulary choices and avoid sweeping generalizations.

Whether anthropologists continue to use the culture concept in a more limited way or avoid it altogether, they have more often than not neglected to address the historical basis of anthropology's inherent separatist and othering stance. This does not only concern the culture concept, but also many other areas that anthropologists deal with, including how we often think today about the concept of religion, for example by demarcating it from secular science, as well as distinguishing anthropology from theology. Debunking the culture concept may be a worthy exercise, but actually moving beyond it or finding constructive solutions to dealing with an orphaned culture concept is a different matter. I suggest that we challenge the divisions and antagonisms that have shaped anthropology and look for inspiration towards the discipline's nemesis, theology.

\section{Theology and the Culture Concept}

During recent years theology and anthropology saw a hesitant but fruitful rapprochement, as scholars argued for better cooperation between the two related disciplines (Bielo 2018; Davies 2002; Fountain 2013; Meneses and Bronkema 2017; Merz 2019; Merz and Merz 2017; Lemons 2018; Robbins 2006). This became possible thanks to the widely recognized failure of secularization theories and the turn to postsecularism, which questions and addresses the artificial divide of the secular and the religious.

This rapprochement, however, has not yet led to theology joining anthropology in questioning the validity and usefulness of the culture concept as such. Rather, systematic theologians have often adopted the culture concept from anthropology together with its deep-seated issues. Accordingly, these theologians continue to use the culture concept to reinterpret the biblical message and church history.

Some systematic theologians have specifically applied the culture concept to theology, mainly to discuss how Christians relate to culture (Carson 2008; Gorringe 2004; Nehrbass 2016; Niebuhr 1951). Others have gone further by comparing theological and anthropological approaches to culture (Flett 2017), while more anthropologically minded Christian scholars have engaged with the concept more deeply, 
also by drawing attention to its shortfalls (Meneses 2009).

Generally, theologians have maintained a more ambivalent relationship to the culture concept when compared with anthropologists. While systematic theologians recognize that culture is "of fundamental theological concern” (Gorringe 2004, 3), opinions differ as to whether it is an essentially human idea that, "like every other facet of creation, stands under the judgment of God" (Carson 2008, 75), or whether "culture is God's idea" (Flett 2017, 209). Kenneth Nehrbass goes even further by claiming "God's nature as a cultural being" (2016, xix) in the sense "that culture is rooted in the very nature of God" $(2016,62)$. What theologians have in common is that they "emphatically emphasized the unity of the human race" (Larsen and King 2018, 51) and thus never accepted cultural relativism to the extent of incommensurability, as has sometimes been the case in anthropology.

While systematic theologians have come up with interesting ways of applying the culture concept to theology, I do not think that they have sufficiently addressed the issues that have since been raised by anthropologists. Despite this, turning to biblical theology shows promise. Kroeber and Kluckhohn point out that biblical authors "showed an interest in the distinctive life-ways of different peoples" $(1952,3)$. This raises the question of how they did this and what both anthropology and a culturally minded theology could learn from looking at how Jesus and Paul dealt with the issue without using the word culture, which was only coined relatively recently.

\section{Jesus and Paul on Human Diversity and Difference}

The Bible is a collection of diverse texts of different genres, written by different people at different times and in different places, and different cultural environments. It is in itself an example of diversity, which has its origin with God and has been part of humanity from the very beginning: "God created mankind in his own image, . . - male and female he created them" (Genesis 1:27, NIV). 'Adam and Eve's children showed economic diversification with Abel being a shepherd and Cain a farmer (Genesis 4:2). Then, the Table of Nations (Genesis 10) demonstrates that humanity spread across the region and diversified through the development of different languages, social and political structures. God cares for all people, regardless of their origins, since through Abraham's “offspring all nations [ethnic groups] on earth will be blessed" (Genesis 22:18, NIV).
Human diversity is a theme that runs through the Bible right to Revelation, where we read that "there before me was a great multitude that no one could count, from every nation, tribe, people and language" (7:9, NIV). This means that cultural diversity-as we might call it today-is an important, integral and valued part of humanity from creation to the last book of the Bible. Such diversity and difference, I need to note, have never been easy to handle, as anthropology's discussion of the culture concept demonstrates. Often, diversity and difference lead to strife, conflict, and crime, especially when people lose sight of their shared human commonality and pursue their own self-interest.

Among humanity's growing diversity, the Israelites developed as a people and nation with an identity founded on God. They constantly struggled to maintain cohesion and unity as they sought to set themselves apart for God and from other peoples. Yet, they also demonstrated an openness to diversity, as illustrated by Moses' Cushite wife (Numbers 12:1), Ruth, the Moabite whom the Israelite Boaz married (Ruth 4:9), or Rahab, the Canaanite prostitute who joined the Israelites with her family (Joshua 2).

As God having become human, Jesus adopted an essentially anthropocentric stance (Flett 2017, 209). Jesus was born into a Jewish family with a genealogy that shows evidence of diversity (Matthew 1:1-17). He was clearly familiar with his complex multicultural and multilingual environment, in which he consciously challenged and disrespected social, religious and cultural identities, authority, boundaries, and conventions when needed. He associated with different outcasts, including prostitutes, lepers, and tax collectors, and interacted with non-Jews when opportunities presented themselves. Whether separatist Samaritan (John 4:4-26), immigrant Greek (Mark 7:25-30) or occupying Roman (Luke 7:2-10), Jesus treated people first of all as persons, created in God's image, even though he was well aware of their social, cultural, and religious differences. Jesus thus recognized what others may refer to as "culture," but he avoided the potentially divisive nature of difference by focusing his attention on people.

Various relationships with God and between humans are more often than not marred by human diversity and difference. Jesus calls us to love others as we love ourselves (Luke 10:27), and even to love our enemies (Luke 6:27-31), whom we often perceive as radically different. Jesus thus presents love as the practical action that should bring different people together and lead at least to an acceptance, if not appreciation, of human diversity.

\footnotetext{
' Scripture quotations taken from The Holy Bible, New International Version® NIV®, Copyright (C) 1973197819842011 by Biblica, Inc. ${ }^{\text {TM }}$. Used by permission. All rights reserved worldwide.
} 
Saul's experience on the road to Damascus-"the model of Christian conversion” (Robbins 2010, 637)_ was as much a turn to Jesus' anthropocentric approach to humanity, diversity and difference as it was an inner spiritual reorientation. Through "a process of relational transformation" (Holbraad and Pedersen 2017, 260; Hurley 2018), Saul turned from a hater of difference and persecutor of Jesus-followers into Paul, a loving servant to humanity in all its diversity. He followed Jesus' example of affirming our shared humanity stemming from creation (Acts 17:26; Larsen and King 2018, 50), while recognizing diversity, which was evident in wider society as different people led their lives differently.

Paul's mission, in a nutshell, was to restore humanity's relationship with God, now made possible through Jesus' sacrificial death and resurrection. The ideal of unity and cohesion founded on their relationship with God, with which the Israelites constantly struggled, now extends to all humans. God made this possible by tearing down the ultimate barrier between himself and humanity and immersing himself in human diversity and difference by becoming human in Jesus. His life, words, and deeds revealed how human diversity was both inevitable and necessary, while his death and resurrection made the new-found unity of all humanity possible. Prior barriers between Israelites, Greeks and Romans were no more. Paul uses the image of a body to show how this unity works in all its diversity (1 Corinthians 12:12-31). Each member of a community has something unique and valuable to contribute to the group.

Paul, like Jesus, was born a Jew and never denied his roots. Following Jesus, he sought to embrace diversity in unity by questioning ethnic identities and by disentangling himself from his own background:

Though I am free and belong to no none, I have made myself a slave to everyone, to win as many as possible. To the Jews I became like a Jew, to win the Jews. To those under the law I became like one under the law (though I myself am not under the law), so as to win those under the law. To those not having the law I became like one not having the law (though I am not free from God's law but am under Christ's law), so as to win those not having the law.... I have become all things to all people so that by all possible means I might save some (1 Corinthians 9:19-22, NIV).

The critical event that validated Paul's views was the Council at Jerusalem (Acts 15:1-21). Paul insisted that non-Jewish Jesus-followers did not need to fulfill Moses' law and be circumcised, which meant that they did not need to become Jews and take on a Jewish identity before being accepted as Jesus-followers. Paul thus freed his message from culturally specific restraints by focusing on the relationship of the One God with humanity. This made it possible for the movement of Jesus-followers to spread easily across social, cultural, religious, and geographical boundaries (Robbins 2010, 648). Christianity thus became a global and transnational movement distinguished by its translatability (Sanneh 2009).

Given that the culture concept is relatively recent, there is no Hebrew or Greek equivalent for the word "culture" in the Bible. Despite this, the anthropological and divisive ideas behind it might have been part of the mindset of Saul, the persecutor of Christians. But I think it opposes the message of Jesus and Paul. They did not see diversity and difference as part of what we call "culture" today, but rather rooted in human commonality as created by God. Such unity in diversity is a basis for any kind of relationship and engagement with others, both theologically and anthropologically. It is equally the basis for communicating, sharing our lives with others, and engaging in relationships. In doing so, we should lovingly and humbly focus our attention on people and-even if we do not always agree with otherswe should abstain from hasty judgements and expect diversity and difference in how we think, act, communicate, and live as part of being human.

We may not think of Jesus and Paul as anthropologists, but their thoughts and lives demonstrate a high level of social and cultural awareness and what I call the ability to thinking anthropologically (Merz 2019). Like early anthropologists, they questioned and challenged their backgrounds and relativized themselves in order to be better placed to focus on other people and understand them and their thoughts and actions. Current anthropologists refer to this as reflexivity or "the ability to think about thinking" (Evens, Handelman, and Roberts 2016, 2) and view it as an essential tool to address concerns brought to light during the crisis of representation, and to address issues relating to the culture concept (Holbraad and Pedersen 2017; Lichterman 2017; Salzman 2002).

Furthermore, Paul, more than Jesus, actively engaged in deconstructing divisions and dichotomies, and especially the idea of different identities. For Paul: "There is neither Jew nor Gentile, neither slave nor free, nor is there male and female, for you are all one in Christ Jesus" (Galatians 3:28, NIV). This kind of deconstructive activity has been another central outcome of the crisis of representation and the debunking of the culture concept, whether it concerns us and them, subject and object, male and female, the secular and religious, modern and traditional, or spirit and matter (Eriksen and Nielsen 2013, 132, 177, 186, 201; Henare, Holbraad, and Wastell 2007; Holbraad 
and Pedersen 2017, 46-48; Josephson-Storm 2017; Merz and Merz 2017; J. D. Moore 2009, 334).

When it comes to the question of culture, I see Jesus and Paul in line with anthropologists who argue for debunking the culture concept. The example set by Jesus and Paul, I suggest, appears remarkably current and pertinent to contemporary anthropology. Had the word "culture" existed, I do not think they would have used it as a central analytical concept, subscribing neither to Romantic nor Enlightenment philosophy. Their message is not about building nations and barriers, but rather about tearing them down as part of establishing the kingdom of God. Their focus on people demonstrates that we not only need to keep human commonality and diversity in balance (Merz $2019,3)$, we also need to root diversity in unity.

Taking Jesus' and Paul's anthropocentric approach as a starting point, I propose that we should shift our anthropological attention from studying the abstract and contentious concept of culture back to people (or anthropos) as anthropology's main topic. While this does not mean that we need to give up on the idea of culture, it does require that we relinquish the culture concept, which is rooted in Enlightenment ideologies.

\section{From Culture to People}

The Enlightenment roots of the culture concept resulted in people aiming to describe and classify cultures, or, in other words, seeking to know cultures in an epistemological sense. Consequently, people ask what a culture is, how it is characterized or patterned, and what distinguishes one culture from another. In shifting our attention to people, we can take a similar approach and ask what a human is and how different people lead different lives, and think, communicate, and act differently.

We should, however, go a step further, as Bronislaw K. Malinowski already proposed in 1922 before the culture concept was widely popularized. For him-in the language of his time-the goal of anthropology is "to grasp the native's point of view, his relation to life, to realize his vision of his world" (1922, 25, emphasis in original). Anthropology, then, is more than a cognitive activity resulting in knowledge and concepts. More importantly, doing anthropology is to practice empathy towards people, and communicate and engage with them in relationships, so that we can put ourselves in the place of our counterparts. This begs the general question of what it is to be human in all our diversity, which requires a different kind of thinking that is embedded in action and relationships, and thus has an ontological focus.

Ontological anthropologists shift their attention from culture to ontology, by which they understand "the investigation and theorization of diverse experiences and understandings of the nature of being itself" (Scott 2013, 859). Knowing about others by learning about different "cultures" is not sufficient to take people themselves seriously. Rather we should also study who people are and seek to grasp their perspectives on the world and how they think, act, and lead their lives. In doing so, we should abstain from limiting ourselves to our own theories and concepts, such as the culture concept, but seek to theorize on the basis of our counterparts' experiences (Henare, Holbraad, and Wastell 2007). Furthermore, opening up anthropology to different epistemological and ontological views, and thus to different ways of thinking and living, is essential for anthropologists from diverse social, cultural, and religious backgrounds to be able to contribute to the discipline without being restrained by culturally and ideologically limited concepts, such as culture (Merz and Merz 2017, 11).

For Martin Holbraad and Morten A. Pedersen, ontological anthropology is above all a "methodological project that poses ontological questions to solve epistemological problems" $(2017,5)$. Their main question is: "How do I enable my ethnographic material to reveal itself to me by allowing it to dictate its own terms of engagement, so to speak, guiding or compelling me to see things that I had not expected, or imagined, to be there?" $(2017,5)$. This requires a personal investment through a deep engagement with people who sometimes appear radically different-and even repugnant (Harding 1991)-to us. In doing so we need to relativize ourselves through reflexivity as much as we reflect on our counterparts (Holbraad and Pedersen 2017, 9-10; Merz 2019, 4-6). The locus of such an engagement can be called the ontological penumbra and is the shady area "where the self and the other, belief and disbelief, ignorance and certainty, possibility and impossibility, .. . meet, overlap and intertwine" (Merz and Merz 2017, 9).

At this point we catch up again with Jesus and Paul, who also had an ontological agenda. They showed love and empathy to people regardless of diverse origins and backgrounds, listened to them and sought to understand them. They refused to accept their own social and cultural backgrounds as the ultimate standard and always kept the idea of a human commonality based on God's image in focus. If we do not root human diversity and difference in our shared humanity, we continue to face the challenges of incommensurability and hyper-relativism that results from overemphasizing radical diversity and alterity.

As has been the case with the culture concept, critics of ontological anthropology have pointed out that the idea of ontology can also result in a view of ontological uniformity and boundedness of a specific group of people, and ultimately lead to the idea of separate multiple ontologies (Harris and Robb 2012). Ontology 
can go as far as "discard[ing] the notion of shared humanity" (Vigh and Sausdal 2014, 54), thus doubting that we are even able to "connect to incommensurable worlds, and translate them into understandable anthropological text" (Vigh and Sausdal 2014, 57; see also, Harris and Robb 2012; Scott 2013).

As is the case with culture, to view ontology as a form of radical alterity or difference can lead to a hyperrelativism that reifies and essentializes ontology thereby raising the question whether "ontology is just another word for culture" (Venkatesan 2010). In order to avoid such a development-as with culture-we should also avoid employing ontology as a noun and use it as an adverb or adjective instead (Holbraad and Pedersen $2017,11)$. Ontological anthropology, then, provides not so much a conceptual as a methodological reorientation to the discipline by refocusing the questions we ask on and about people.

We are then left with the most basic ontological question that anthropology can ask, namely "what it is to be human" (Toren 2002; see also, Eriksen 2010, 197; Eriksen and Nielsen 2013, 203, 219; Merz 2019, 2; 2020, 136; Merz and Merz 2017, 2). Having said this, anthropology does not-and should not-have a monopoly on this question, since it shares it with other academic disciplines, including theology (Maston 2018, 2). Anthropology's particular contribution to the study of humans is to examine and seek to understand the human diversity we find in different places, times, and relationships, and how people think, communicate, and engage with each other, God, and, in a wider sense, the surrounding world. Anthropologists seek to focus on how different people see themselves, including the possibility of discovering what we cannot anticipate or imagine.

In studying people, we should abstain from dehumanizing them by analyzing and subsuming them under "culture" (or "ontology") and thus othering them by making them conform to our ideas of what culture is and does. "Culture" cannot-and should not be used to-define humans. Rather, it is our diverse and different ways of life through which we engage with each other and the world around us that shape our various social and cultural environments, as much as these shape us. In this sense, humanity's shared predisposition for diversity and difference means that "the human being is essentially a social being, and therefore an irreducibly cultural being" (Flett 2017, 214, emphasis in original; see also, Merz 2019, 4; Wason 2017, 14).

While I consider it imperative to give up on the Enlightenment idea of culture as a noun and defining concept of anthropology, I am happy to use the word as an adjective or adverb. Current anthropology shows that this can help us describe, discuss, and understand human diversity and difference. This, in turn, affects the way we behave, communicate, and live out our lives with each other, God, and in the world we all inhabit.

This brings me back to the beginning of this article. Shifting our attention from culture to people has wideranging and deep implications. It does not only come with a methodological shift towards ontological anthropology, it also means a breaking down of Enlightenment oppositions, barriers, and dichotomies. Anthropology should no longer maintain its early anti-religious and separatist stance through the conceptual and ideological basis of culture, but accept the important and valid idea of culture when used as an adjective to describe humans in all their diversity. This places anthropology in a position where it can converge with theology and other disciplines through the idea of cultural diversity and difference being rooted in human commonality. In this way, anthropology opens itself up in ways hardly possible before.

This paves the way for deeper collaboration across disciplines with similar concerns and questions. Even though anthropology and theology continue to have different approaches, focuses and agendas, both take humanity as their main concern and are thus "equally interested in human flourishing" (Bielo 2018, 33). It is on this basis that further collaboration could-and should-develop.

\section{Conclusion}

The vast diversity and alterity of humanity we observe in today's world may appear to be cultural in nature, but rather than conceiving of them in terms of different cultures, we should root them in humanity's commonality. I explore this idea by looking at Jesus and Paul and how they dealt with issues of diversity and difference. Their approach of tearing down barriers and deconstructing identities as a reflexive engagement with themselves and others is a manner of anthropological thinking that I find remarkably current. By focusing on people regardless of their social, cultural, and religious backgrounds, Jesus' and Paul's approach further aligns with the current preoccupations of ontological anthropology. Jesus and Paul, then, help us to move the discipline's focus back to people (or anthropos) in all their social and cultural diversity and difference.

The shift from culture to people comes with both conceptual and methodological changes. Conceptually -and in line with current anthropology-we should reject the culture concept given that it is a specific ideological construct that makes people other by dividing them into bounded units. Instead, we should consider using wider, more nuanced and flexible vocabulary to help us understand and talk about diversity, such as society, community, identity, and worldview, and adjectival expressions such as cultural 
environment, cultural background, cultural issues, and cultural features. Furthermore, anthropology needs to embrace epistemological, ontological, and religious ideas of difference that stem from outside the discipline as part of theorizing and doing anthropology. Methodologically, anthropology can no longer limit itself to cognitive knowledge, but must also embrace practical, reflexive, and ontological engagements with others. This helps us to take people seriously by seeking to understand who they are, as well as the way they see themselves and the world.

Taken together, these conceptual and methodological reorientations open up anthropology to people from all social, cultural, and religious backgrounds so that they can engage in the discipline and contribute novel ideas and thus diversify anthropology's theoretical repertoire. Similarly, this will help anthropology move beyond the limits of its own ideological views and concepts, and to collaborate with disciplines that have similar preoccupations, such as theology, by contributing its expertise on cultural diversity and difference.

Today, with the debunking of the culture concept, many anthropologists no longer document the cultures of people groups as wholes. They rather study what it is to be human in specific situations and how people relate to each other and the world around them. It is only once we seek to grasp other people's diverse perspectives, and put our feet into their shoes, that we can contribute to the overarching question of what it is to be human, both particularly and generally. After all, anthropologists are not that different from theologians in wanting to see people flourish in their various relationships with each other, the world around them, and maybe even with God.

\section{References}

Abu-Lughod, Lila. 1991. Writing against Culture. In Recapturing Anthropology: Working in the Present. Richard G. Fox, ed. Pp. 137-162. Santa Fe, CA: School of American Research Press.

Barnard, Alan and Jonathan Spencer. 2010. Culture. In The Routledge Encyclopedia of Social and Cultural Anthropology, second edition. Alan Barnard and Jonathan Spencer, eds. Pp. 168-176. New York and London: Routledge.

Benedict, Ruth. 1934. Patterns of Culture. Boston and New York: Houghton Mifflin.

Bielo, James S. 2018. Anthropology, Theology, Critique. Critical Research on Religion 6 (1): 28-34.
Brightman, Robert. 1995. Forget Culture: Replacement, Transcendence, Relexification. Cultural Anthropology 10 (4): 509-546.

Brumann, Christoph. 1999. Writing for Culture: Why a Successful Concept Should Not be Discarded. Current Anthropology 40: 1-27.

Carson, D. A. 2008. Christ and Culture Revisited. Norton Street, UK: Apollos.

Clifford, James. 1986. Introduction: Partial Truths. In Writing Culture: The Poetics and Politics of Ethnography. James Clifford and George E. Marcus, eds. Pp. 1-26. Berkeley, CA: University of California Press.

Clifford, James and George E. Marcus, eds. 1986. Writing Culture: The Poetics and Politics of Ethnography. Berkeley, CA: University of California Press.

Davies, Douglas J. 2002. Anthropology and Theology. Oxford and New York: Berg.

Engelke, Matthew. 2018. How to Think Like an Anthropologist. Princeton, NJ: Princeton University Press.

Eriksen, Thomas Hylland. 2010. The Challenges of Anthropology. International Journal of Pluralism and Economics Education 1 (3): 194-202.

Eriksen, Thomas Hylland and Finn Sivert Nielsen. 2013. A History of Anthropology, second edition. London: Pluto Press.

Evens, Terry, Don Handelman, and Christopher Roberts. 2016. Introduction: Reflexivity and Selfhood. In Reflecting on Reflexivity: The Human Condition as an Ontological Surprise. Terry Evens, Don Handelman, and Christopher Roberts, eds. Pp. 1-20. New York and Oxford: Berghahn Books.

Flett, Eric G. 2017. Trinity: Conceptual Tools for an Interdisciplinary Theology of Culture. In On Knowing Humanity: Insights from Theology for Anthropology. Eloise Meneses and David Bronkema, eds. Pp. 209-221. London and New York: Routledge.

Fountain, Philip. 2013. Toward a Post-secular Anthropology. The Australian Journal of Anthropology 24 (3): 310-328

Geertz, Clifford. 1973. The Interpretation of Cultures: Selected Essays. New York: Basic Books.

Gorringe, T. J. 2004. Furthering Humanity: A Theology of Culture. Aldershot: Ashgate.

Gupta, Akhil and James Ferguson. 1992. Beyond "Culture": Space, Identity, and the Politics of Difference. Current Anthropology 7 (1): 6-23. 
Harding, Susan. 1991. Representing Fundamentalism: The Problem of the Repugnant Cultural Other. Social Research 58 (2): 373-393.

Harris, Oliver J. T. and John Robb. 2012. Multiple Ontologies and the Problem of the Body in History. American Anthropologist 114 (4): 668-679.

Henare, Amiria, Martin Holbraad, and Sari Wastell. 2007. Introduction: Thinking Through Things. In Thinking Through Things: Theorising Artefacts Ethnographically. Amiria Henare, Martin Holbraad, and Sari Wastell, eds. Pp. 1-31. London: Routledge.

Holbraad, Martin and Morten A. Pedersen. 2017. The Ontological Turn: An Anthropological Exposition. Cambridge: Cambridge University Press.

Hurley, Jill. 2018. Understanding Christian Conversion as a Post-Relational Ontological (Re)turn to Relations. On Knowing Humanity Journal 2 (2): 1-8.

Josephson-Storm, Jason A. 2017. The Myth of Disenchantment: Magic, Modernity, and the Birth of the Human Sciences. Chicago: The University of Chicago Press.

Kahn, Joel S. 1989. Culture: Demise or Resurrection? Critique of Anthropology 9 (2): 5-25.

Keesing, Roger M. 1990. Theories of Culture Revisited. Canberra Anthropology 13 (2): 46-60.

Kroeber, A. L. and Clyde Kluckhohn. 1952. Culture: $A$ Critical Review of Concepts and Definitions. Cambridge, MA: The Museum.

Larsen, Timothy. 2014. The Slain God: Anthropologists and the Christian Faith. Oxford: Oxford University Press.

Larsen, Timothy and Daniel J. King. 2018. The Dependence of Sociocultural Anthropology on Theological Anthropology. In Theologically Engaged Anthropology: Social Anthropology and Theology in Conversation. Derrick J. Lemons, ed. Pp. 50-65. Oxford: Oxford University Press.

Lemons, Derrick J., ed. 2018. Theologically Engaged Anthropology: Social Anthropology and Theology in Conversation. Oxford: Oxford University Press.

Lentz, Carola. 2017. Culture: The Making, Unmaking and Remaking of an Anthropological Concept. Zeitschrift für Ethnologie 142 (2): 181-204.

Lichterman, Paul. 2017. Interpretive Reflexivity in Ethnography. Ethnography 18 (1): 35-45.

Malinowski, Bronislaw K. 1922. Argonauts of the Western Pacific. London: Kegan Paul.
Marcus, George E. and Michael M. J. Fischer. 1986. Anthropology as Cultural Critique: An Experimental Moment in the Human Sciences. Chicago: The University of Chicago Press.

Maston, Jason. 2018. Introduction. In Anthropology and the New Testament. Jason Maston and Benjamin E. Reynolds, eds. Pp. 1-4. London and New York: T\&T Clark.

Mead, Margaret. 1928. Coming of Age in Samoa: A Psychological Study of Primitive Youth for Western Civilisation. New York: Blue Ribbon Books.

Meneses, Eloise and David Bronkema, eds. 2017. On Knowing Humanity: Insights from Theology for Anthropology. London and New York: Routledge.

Meneses, Eloise Hiebert. 2009. The Birds of the Air: The Christian Challenge to Culture in Defending the Marginalized. Missiology: An International Review 37 (3): 369-384.

Merz, Johannes. 2019. Thinking Anthropologically for the Theologically and Missiologically Engaged. On Knowing Humanity Journal 3 (2): 1-13. 2020. The Culture Problem: How the Honor/Shame Issue Got the Wrong End of the Anthropological Stick. Missiology: An International Review 48 (2): 127-141.

Merz, Johannes and Sharon Merz. 2017. Occupying the Ontological Penumbra: Towards a Postsecular and Theologically Minded Anthropology. Religions 8 (5): 117. http://www.mdpi.com/2077-1444/8/5/80. Accessed 28 April 2017.

Moore, Jerry D. 2009. Visions of Culture: An Introduction to Anthropological Theories and Theorists, third edition. Lanham, MD: Altamira Press.

Moore, John H. 1974. The Culture Concept as Ideology. American Ethnologist 1 (3): 537-549.

Nehrbass, Kenneth. 2016. God's Image and Global Cultures: Integrating Faith and Culture in the Twentyfirst Century. Eugene, OR: Cascade Books.

Niebuhr, H. Richard. 1951. Christ and Culture. New York: Harper and Row.

Radcliffe-Brown, A. R. 1952. Structure and Function in Primitive Society: Essays and Addresses. Glencoe, IL: The Free Press.

Robbins, Joel. 2006. Anthropology and Theology: An Awkward Relationship? Anthropological Quarterly 79 (2): 285-294. . 2010. Anthropology, Pentecostalism, and the New Paul: Conversion, Event, and Social Transformation. South Atlantic Quarterly 109 (4): 633-652. 
Rodseth, Lars. 2018. Hegemonic Concepts of Culture: The Checkered History of Dark Anthropology. American Anthropologist 120 (3): 398-411.

Salzman, Philip Carl. 2002. On Reflexivity. American Anthropologist 104 (3): 805-811.

Sanneh, Lamin. 2009. Translating the Message: The Missionary Impact on Culture, second edition, revised and expanded. Maryknoll, NY: Orbis Books.

Schwartz, Saul. 2018. The Predicament of Language and Culture: Advocacy, Anthropology, and Dormant Language Communities. Journal of Linguistic Anthropology 28 (3): 332-355.

Scott, Michael W. 2013. The Anthropology of Ontology (Religious Science?). Journal of the Royal Anthropological Institute 19 (4): 859-872.

Silverstein, Michael. 2005. Languages/Cultures Are Dead! Long Live the Linguistic-Cultural! In Unwrapping the Sacred Bundle: Reflections on the Disciplining of Anthropology. Daniel A. Segal and Sylvia J. Yanagisako, eds. Pp. 99-125. Durham, NC: Duke University Press.

Spradley, James P. 1979. The Ethnographic Interview. New York: Holt, Rinehart, and Winston.

Toren, Christina. 2002. Anthropology as the Whole Science of What It Is to Be Human. In Anthropology Beyond Culture. Richard G. Fox and Barbara J. King, eds. Pp. 105-125. Oxford and New York: Berg.

Tylor, Edward B. 1871. Primitive Culture: Researches into the Development of Mythology, Philosophy, Religion, Language, Art, and Custom, two volumes. London: John Murray.

Venkatesan, Soumhya, ed. 2010. Ontology Is Just Another Word for Culture: Motion Tabled at the 2008 Meeting of the Group for Debates in Anthropological Theory, University of Manchester. Critique of Anthropology 30 (2): 152-200.

Vigh, Henrik Erdman and David Brehm Sausdal. 2014. From Essence Back to Existence: Anthropology Beyond the Ontological Turn. Anthropological Theory 14 (1): 49-73.

Wason, Paul. 2017. The Difference Culture Makes. On Knowing Humanity Journal 1 (1): 14-24.

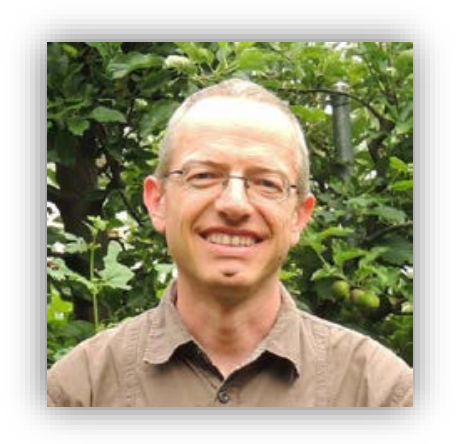

Johannes Merz is a senior anthropology consultant with SIL International. He has a $\mathrm{PhD}$ in cultural anthropology from Leiden University, the Netherlands. Together with Sharon Merz, he has been based in Benin, West Africa, since 2002. One of his goals is to promote anthropology by making it more accessible beyond the discipline. Johannes regularly offers courses and workshops, and lectures at Moorlands College, Christchurch, UK, and the Theological College of Northern Nigeria, Jos, Nigeria.

Author email: johannes_merz@sil.org 